\title{
EFFECTS OF LONG TERM STORAGE ON AEROSPACE NICKEL CADMIUM CELL PERFORMANCE
}

\author{
Thomas Y. Yi \\ Space Power Applications Branch, Code 711 \\ NASA/Goddard Space Flight Center \\ Greenbelt, MD 20771
}

SUMMARY

\begin{abstract}
A study currently being perfromed at NASA/Goddard Space Flight Center (GSFC) to evaluate the long term effects on aerospace nickel cadmium cells is described. A number of $6 \mathrm{Ah}$ and $12 \mathrm{Ah}$ capacity cells which have been stored in shorted condition for 9 to 11 years at the GSFC have been selected for this study. Of the three tests which have been initiated (initial and final destructive analyses of the test cells, GSFC electrical characterization tests, and life cycling tests) only the GSFC electrical characterization tests have been completed; other tests are scheduled to be completed by February, 1987. The preliminary electrical performance data from the life cycling test and chemical composition data from the destructive testing indicate no anomalous behavior.
\end{abstract}

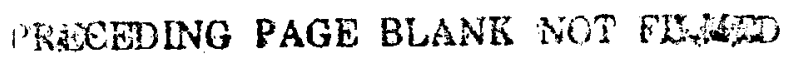




\section{INTRODUCTION}

Investigation of long term storage effects on aerospace nickel cadmium cell performance is an important topic that has generated little interest. Although many works have been published on the performance of a nickel cadmium cell, relatively few studies have been addressed on the effects of prolonged storage of these cells in the recent years.

This topic is especially important to NASA in that we are interested in the reliability of a cell which has been stored for an extended period of time after activation. Cells for a flight project are procured, tested, made into battery packs, and placed in cold storage well in advance of the launch date. Inevitably because of launch delays, the question of cell reliability as a function of storage time is often asked. Originally NASA/Goddard Space Flight Center (GSFC) placed an arbitrary 18 months age limit on nickel cadmium cells held in storage for a spacecraft launch; this judgment limit was later extended to 24 to 36 months. At present we at GSFC do not like to store cells for more than 3 to 4 years after activation prior to the launch date, although there are data supporting storage periods of up to 5 years. With more studies on the topic of storage effects we may be able to extend our storage time limit.

A number of studies have addressed the issue of the long term storage effects on nickel cadmium cells [1-13]. Bogner who tested the cells after a 6-month storage at $10^{\circ} \mathrm{C}$ reported that the capacity of the cell packs was as good or better after storage [2]. Scott has studied the effects of storing batteries, which were shorted and stored at 5 to $10^{\circ} \mathrm{C}$, over a 4-year period. He found no appreciable adverse effect over this time frame, and he suggested that the batteries can be store up to 5 years when the cells are shorted, and at a fairly low temperature [3]. Similarly Stanley reported that shorted storage has proved to be effective for up to 5 years without significant degradation [4]. Thierfelder et al. reported that the swelling of the positive plates and the decrease in overcharge protection are found to be the life limiting characteristics during prolonged storage [5]. They recommended a maximum cell age of 3.5 
years at time of spacecraft launch for a 7.5 year mission. Brahim et al. found that the cells retained a significant efficiency after 5 years of storage [6]. However Hobbs et al., based on their initial data, suggest that storage effects will constitute a major problem [7]. They later reported reductions in capacity between $1 \%$ and $75 \%$ after a 3 year storage period mode, depending on the cell model, storage temperature, and storage time [8]. I would like to point out that the nickel cadmium cells studied by Brahim et al. and Hobbs et al. were of commercial grade, not of aerospace quality.

Most of the aerospace cells used in the above studies were manufactured in the 1960's, whereas the cells used in this study, in the 1970's. The cells used in this study resemble the present day nickel cadmium cells in characteristics and construction more closely than most of the cells used in the above works. Because the cells used in this study were fabricated at a later date, these cells have been manufactured under refined process and under better quality control than most of those cells in the above works; these cells have been manufactured and tested, adhering closely to NASA/GSFC Specification 74-15000, Specification for Manufacturing of Aerospace Nickel-Cadmium Storage Cells [14].

This study was initiated to investigate the effects of long term storage on aerospace nickel cadmium cells via electrical acceptance testing, simulated flight conditions at both real time and accelerated time testing, and destructive analysis. The cells selected for this study have been stored at room temperature under shorted condition in the Battery Lab at GSFC for 9 to 11 years. The results from the study will be compared with previous data on these cells, namely from the initial acceptance data at GSFC, and from the life cycling data on cells from the same lot at NASA Battery Facility at Naval Weapons Support Center (NWSC) in Crane, IN. We have selected General Electric (G.E.) 6Ah and 12Ah nickel cadmium cells for this study. These cells have been chosen because of their relative abundance in the Battery Lab, and also because of availability of their GSFC acceptance data and NWSC life cycling data. Specific information on these cells is mentioned elsewhere [15-20]. The test plans along with the preliminary data were first presented at the 1985 NASA/GSFC Battery 
Workshop [21-22].

\section{TEST DESCRIPTION}

For this study twelve cells have been selected from each of the IUE (International Ultraviolet Explorere satellite) $6 \mathrm{Ah}$ and $12 \mathrm{Ah}$ cell lots at the Battery Lab at GSFC. Of the 12 cells within a lot, 2 cells underwent destructive analysis at Bowie State College in Bowie, MD, following the procedures outlined in the NASA document X-711-74-279 [23]. The remaining 10 cells from each lot were fabricated into two 5-cell packs, one of which was tested at the Battery Lab at GSFC, and the other at NWSC. The steps in the GSFC electrical characterization test are outlined in Table 1 . The operating parameters of the NWSC life testing packs are listed in Table 2. The 6AH test pack is currently undergoing accelerated geosynchronous orbit cycling (GEO), whereas the $12 \mathrm{AH}$ pack is operating at real time low earth orbit (LEO) cycling. These test parameters were deliberately chosen to operate under the same operating conditions as pack $231 \mathrm{~A}$ for the $6 \mathrm{AH}$ pack, and pack $8 \mathrm{G}$ for the $12 \mathrm{AH}$ pack at NWSC [24-31]. The specifics of the GSFC and NWSC tests were reported at the 1985 NASA/GSFC Battery Workshop, and are available elsewhere [21-22].

\section{RESULTS AND DISCUSSION}

Only those tests at GSFC have been completed at this time. Therefore, the bulk of the discussion will be on the results from those tests.

\section{GSFC Electrical Characterization Tests}

Electrical characterization tests as outlined in Table 1 in the Test Description section has been 
completed on the selected G.E. $6 \mathrm{Ah}$ and 12Ah cells. Figures 1 and 2 compare the cell capacities at different charge rates and temperatures for the $6 \mathrm{Ah}$ and $12 \mathrm{Ah}$ cells, respectively. The preliminary indication shows that both the 6Ah and 12Ah cells have improved their cell capacities after 9 to 11 years of storage. Moreover both the cell and third electrode voltages at end-of-charge (EOC) have either remained the same or have increased after the storage period.

Our observation that cell capacities increase with storage time is of great concern. Although such observation has been reported by Bogner [2], it is generally believed that cells degrade over long length of time, principally due to degradation of the separator material, nylon. Real time synchronous orbit tests and some LEO test have shown a gradual increase in the cell ampere-hour capacities during the early cycles of life testing. Such increases may result either from incomplete formation of the positive plates during cell manufacturing, or from inadequate active "excess charged" negative capacity at the beginning of cycling [32]. Scott found that a very large percentage of changes is introduced during acceptance testing, and that very little additional changes during shorted storage [11]. The tested nickel cadmium cells have been stored shorted after some 30 cycles of testing in the original acceptance test. These two ideas suggest that the tested IUE cells are more affected by the GSFC electrical characterization test than by storage. If so, the tested IUE cells may exhibit a slight increase in their cell capacities at beginning-of-life (BOL); we must wait until the life tests are completed to reach any conclusion.

All the 6AH cells have met the performance specification as outlined in the Cell Acceptance Test Plan [33-34]. From Fig. 1 , we note that for either test dates, we see the generally observed cell behavior that cell capacities increase with cycling time, and that the lowest capacity is seen during the overcharge test where the temperature is at $0^{\circ} \mathrm{C}$. For the $12 \mathrm{AH}$ cells, similar behaviors were noted (see Fig. 2). Nearly all the plots from the GSFC electrical characterization tests, of cell voltage versus time, and of third electrode voltage versus time, exhibited normal cell characteristics. 
The third electrode voltage plots for one cell (S/N 014) among the 6Ah cells displayed abnormal behavior, however. This particular cell showed no change in the third electrode voltage for the discharge portions during the second capacity check and during the overcharge test (see Fig. 3 and 4, respectively). For the charge portions of the second capacity check and overcharge test, its third electrode voltage did not change until the cell was fully charged (see Fig. 5 and 6, respectively). Such behaviors for both the charge and discharge periods were not observed in the first capacity check and in the subsequent capacity check or burn-in cycles.

This anomalous behavior of the third electrode is not a cause for an alarm. The third electrode voltage is an "unpredictable" parameter. Baer reported that during his testing of the IUE cells, the third electrode voltage test data revealed a very high degree of nonuniformity [20]. His finding was in accord with Scott and Rusta [32] who stated that from the life cycling data and from flight experience the third electrode performance is not reliable over long periods of time. Besides, the third electrode was not utilized to control charge and discharge, but rather it was used to provide additional data.

\section{NWSC Life Tests}

Life tests for both the $6 \mathrm{AH}$ pack and $12 \mathrm{AH}$ pack are scheduled to be completed by February, 1987. . To date, the $6 \mathrm{AH}$ pack, which is labelled as pack 231C at NWSC, has undergone 9 accelerated shadow periods; the $12 \mathrm{AH}$ pack, which is labelled as pack $8 \mathrm{I}$, has undergone about $5000 \mathrm{LEO}$ cycles. The latest data from NWSC on packs $231 \mathrm{C}$ and $8 \mathrm{I}$ are plotted in Figures 7 and 8, respectively. In Fig. 7, pack $231 \mathrm{C}$ has completed its eighth shadow period, i.e., equivalent of 4 years of synchronous cycling. The plot of cell capacity check for pack $231 \mathrm{C}$ is shown in Figure 9; the cells have not lost any capacities after eight shadow periods. In Fig. 8, pack 8 I has completed 4552 LEO cycles. These plots exhibit normal cell characteristics. 


\section{Destructive Analyses}

At the beginning of this study, four cells have been sent to Bowie State College, MD, for destructive analysis; the test analyses show no anomalies. Eight more cells will be undergo destructive analysis once the NWSC tests on the cells are completed.

\section{CONCLUSION}

This study was initiated to better understand the effects of long term storage on nickel cadmium cells. The selected cells have passed the GSFC electrical characterization tests; they have been life tested for over 5000 LEO cycles and 9 accelerated GEO shadow periods without failure. Because the tests are still ongoing, no conclusions will be made until all the tests have been completed.

\section{REFERENCES}

1. DiStefano, S. et al., "Studies of the Effect of Aging on the Components of Sealed Nickel Cadmium Cells." Proc. Symp. on the Nickel Electrode, Fall Meeting of the Electrochem. Soc., pp. 216-223.

2. Bogner, R. S. et al., "Cycle Life and Storage Test Results." 1976 GSFC Battery Workshop, NASA X-711-77-28, pp. 215-222.

3. Scott, W., "Long-Term Storage Effects Update." 1977 GSFC Battery Workshop, NASA Conference Publication 2041, pp. 219-222.

4. Stanley, C., Spacecraft Testing, 5-Year Storage Life, USAF/SAMSO Contract F04701-71C-0131, Report 16439-93-002-602, TRW Systems Group, 1976.

5. Thierfelder, H. E. et al., "Nickel Cadmium Cell Age Sensitivity Study." Proc. Intersoc. Eng. Conf., Vol. 1, 1984, pp. 319-323.

6. Braham, R. W. et al., "On the Aging of the Nickel Cadmium Systems." Power Sources, Vol. 6, 1977, pp. 129-159.

7. Hobbs, B. S. et al., "Aspects of Nickel Cadmium Cells in Single Cycle Applications - The Effect of Long Term Storage." J. Appl. Electrochem., Vol. 8, 1978, pp.305-311. 
8. Hobbs, B. S., "Short Circuit Storage Testing of Nickel Cadmium Cells." The City University Report No. 80/26/023, Final Summary Report, London, England, 6/80.

9. Harkness, J., "Storage Effects on Cells." 1977 GSFC Battery Workshop, NASA Conference Publication 2041, pp. 223-242.

10. Dunlop, J., "Storage Experience." 1973 GSFC Battery Workshop, pp. 81-91.

11. Scott, W., "Cells Shorted for Years." 1975 GSFC Battery Workshop, NASA X-711-76-21, pp. 201-207.

12. Scott, W., "Effect of Long Term Activated Shorted Storage." 1974 GSFC Battery Workshop, NASA X-711-74-348, pp. 125-139.

13. Halpert, G., "Effect of Storage Modes on Nickel-Cadmium Cell Condition." 1983 Space Power Workshop, Los Angeles, CA, 3/16/83.

14. "Specification for the Manufacture of Aerospace Nickel Cadmium Storage Cells," NASA/GSFC Specification 74-15000, March 1975.

15. . Tiller, S. "IUE Flight Experience." 1978 GSFC Battery Workshop, NASA Conference Publication 2088, pp. 229-237.

16. Baer, D. "Cell Design." 1976 GSFC Battery Workshop, NASA X-711-77-28, pp. 89-95.

17. Tiller, S. "Update of the IUE Battery In-Flight Performance."

1979 GSFC Battery Workshop, NASA Conference Publication 2117, pp. 215-218.

18. Tiller, S. "Performance of the IUE Spacecraft Batteries After 70 Months." 1983 GSFC Battery Workshop, NASA Conference Publication 2331, pp. 353-365.

19. Tiller, S. "Status Report on the IUE Project Cell Life Test at NWSC-Crane." Internal Memorandum, Dec. 14, 1981.

20. Baer, D. Summary of the Manufacturing and Testing of $12 \mathrm{AH}$ Nickel-Cadmium Cells for the IUE Spacecraft. X-711-76-18, 1/76.

21. Yi, T. "Investigation of Long-Term Storage Effects on Aerospace Nickel-Cadmium Cell Performance." 1985 GSFC Battery Workshop, NASA Conference Publication 2434, pp. 249-254.

22 Yi, T, J. Power Sources, 18(1986) 191.

23. Halpert, G. and Kunigahalli, V. Procedure for Analysis of Nickel-Cadmium Cell Materials, NASA X-711-74-279, Rev. A, 1980.

24. Naval Weapons Support Center. Evaluation Program for Secondary Spacecraft Cells: Synchronous Orbit Testing of Sealed Nickel-Cadmium Cells, Contract S-53742-AG, WQEC/C 81-120A, 1981, pp. 114-133.

25. Naval Weapons Support Center. Evaluation Program for Secondary Spacecraft Cells: Synchronous Orbit Testing of Sealed Nickel-Cadmium Cells, Contract S-53742-AG, WQEC/C 81-120B, 1981, pp. 76-90. 
26. Naval Weapons Support Center. Evaluation Program for Secondary Spacecraft Cells: 16th Annual Report of Cycle Life Test, Contract C-13105-D, WQEC/C 80-34, 1980, pp. 28-32.

27. Naval Weapons Support Center. Evaluation Program for Secondary Spacecraft Cells: 17th Annual Report of Cycle Life Test, Contract C-13105-D, WQEC/C 81-1, 1981, pp. 28-32.

28. Naval Weapons Support Center. Evaluation Program for Secondary Spacecraft Cells: 18th Annual Report of Cycle Life Test, Contract C-13105-D, WQEC/C 82-23, 1982, pp. 29-32.

29. Naval Weapons Support Center. Evaluation Program for Secondary Spacecraft Cells: 19th Annual Report of Cycle Life Test, Contract C-13105-D, WQEC/C 83-1, 1983, pp. 29-33.

30. Naval Weapons Support Center. Evaluation Program for Secondary Spacecraft Cells: 20th Annual Report of Cycle Life Test, Contract C-13105-D, WQEC/C 84-5, 1984, pp. 15-19.

31. Naval Weapons Support Center. Evaluation Program for Secondary Spacecraft Cells: 16th Annual Report of Cycle Life Test, Contract C-13105-D, WQEC/C 85-52, 1985, p. 36.

32. Scott, W. and Rusta, D. Sealed Cell Nickel-Cadmium Battery Applicationsw Manual, NASA RP-1052, 12/79, pp. 350.

33. Tiller, S. Battery Fabrication And Acceptance Test Plan for International Ultraviolet Explorer (IUE) 6AH Batteries, NASA X-711-78-5, 1978.

34. Tiller, S. Cell Acceptance Test Plan for Nickel-Cadmium Cells, NASA X-711-76-143, 1976, pp. 17-19. 
Table 1. Steps used in the GSFC Electrical Characterization Tests

\begin{tabular}{|c|c|c|c|c|c|c|c|c|}
\hline \multirow{2}{*}{$\begin{array}{l}\text { Siqueince } \\
\text { Nunitier }\end{array}$} & \multirow{2}{*}{$\begin{array}{c}\text { Test Cimulitikn } \\
\text { Number }\end{array}$} & \multirow{2}{*}{ Test Deinripinm } & \multirow{2}{*}{$\begin{array}{c}\text { Tempersture } \\
\text { (c) }\end{array}$} & \multirow{2}{*}{ Current } & \multicolumn{2}{|c|}{ Vivltą̧: Limis: } & \multicolumn{2}{|c|}{$\begin{array}{l}\text { Test Wurstinin } \\
\text { (hours) }\end{array}$} \\
\hline & & & & & $\begin{array}{c}\text { Upper Liniu } \\
\text { (V) }\end{array}$ & $\begin{array}{c}\text { Lomer Limst } \\
\text { (V) }\end{array}$ & Specirned & Extimskd \\
\hline 1 & $\begin{array}{l}1 \\
2\end{array}$ & $\begin{array}{l}\text { Conditioning Charge } \\
\text { Conditioning Discharge } \\
\text { Resistive Drain }\end{array}$ & $\begin{array}{l}25 \\
25 \\
25\end{array}$ & $\begin{array}{l}\mathrm{C} / 20 \\
\mathrm{C} / 2 \\
-\end{array}$ & $\begin{array}{l}1.51 \\
1.51 \\
-\end{array}$ & $\begin{array}{l}0.80 \\
0.80 \\
-\end{array}$ & $\begin{array}{ll}4 x \\
-\end{array}$ & $\overline{3}$ \\
\hline $\begin{array}{l}3 \\
4\end{array}$ & $\begin{array}{l}3 \\
2\end{array}$ & $\begin{array}{l}\text { Conditioning Charge } \\
\text { Conditioning Discharge } \\
\text { Resistive Drain/Temperoture Stabilization }\end{array}$ & $\begin{array}{l}25 \\
25 \\
20\end{array}$ & $\begin{array}{l}C / 10 \\
C \cdot 2 \\
-\end{array}$ & $\begin{array}{l}1.51 \\
1.51\end{array}$ & $\begin{array}{l}0.80 \\
0.80 \\
-\end{array}$ & $\frac{24}{-}$ & $\begin{array}{l}- \\
3\end{array}$ \\
\hline $\begin{array}{l}5 \\
6\end{array}$ & 5 & $\begin{array}{l}\text { Capacity Charge } \\
\text { Capacity Discharge } \\
\text { Resistive Drain }\end{array}$ & $\begin{array}{l}20 \\
20 \\
20\end{array}$ & $\begin{array}{l}C / 10 \\
C \Omega \\
-\end{array}$ & $\begin{array}{l}1.51 \\
1.51 \\
-\end{array}$ & $\begin{array}{l}0.80 \\
0.80 \\
-\end{array}$ & $\frac{24}{16}$ & $\begin{array}{l}- \\
-\end{array}$ \\
\hline 7 & 6 & $\begin{array}{l}\text { Charge Retention - Open Circuit } \\
\text { Resistive Drain Temperature Stabilization }\end{array}$ & $\begin{array}{l}20 \\
10\end{array}$ & - & - & - & 24 & $\overline{2}$ \\
\hline $\begin{array}{l}8 \\
9\end{array}$ & $\begin{array}{l}7 \\
8\end{array}$ & $\begin{array}{l}\text { Capacity Charge } \\
\text { Capacity Discharge } \\
\text { Resistive DrainTemperature Stabilization }\end{array}$ & $\begin{array}{r}10 \\
10 \\
0\end{array}$ & $\begin{array}{l}C_{20} \\
C_{2} \\
-\end{array}$ & $\begin{array}{l}1.53 \\
1.53 \\
-\end{array}$ & $\begin{array}{l}0.80 \\
0.80 \\
-\end{array}$ & $\frac{48}{-}$ & $\begin{array}{l}- \\
3\end{array}$ \\
\hline $\begin{array}{l}10 \\
11\end{array}$ & $\begin{array}{r}9 \\
10\end{array}$ & $\begin{array}{l}\text { Overcharge Charge } \\
\text { Overcharge Discharge } \\
\text { Resistive DrainTemperature Siabilization }\end{array}$ & $\begin{array}{r}0 \\
0 \\
10\end{array}$ & $\begin{array}{l}\mathrm{C}_{20} \\
\mathrm{C} \Omega \\
-\end{array}$ & $\begin{array}{l}1.53 \\
1.53 \\
-\end{array}$ & $\begin{array}{c}0.80 \\
0.80 \\
-\end{array}$ & $\frac{72}{-}$ & $\begin{array}{l}- \\
3\end{array}$ \\
\hline $\begin{array}{l}12 \\
13\end{array}$ & $\begin{array}{l}11 \\
12\end{array}$ & $\begin{array}{l}\text { Bum-in Charge } 1 \\
\text { Bum-in Discharge } 1\end{array}$ & $\begin{array}{l}10 \\
10\end{array}$ & $\begin{array}{l}\mathrm{C} 20 \\
\mathrm{C} / 2\end{array}$ & $\begin{array}{l}1.53 \\
1.53\end{array}$ & $\begin{array}{l}0.80 \\
0.80\end{array}$ & $\begin{array}{r}23 \\
1\end{array}$ & - \\
\hline $\begin{array}{l}14 \\
15\end{array}$ & $\begin{array}{l}11 \\
12\end{array}$ & $\begin{array}{l}\text { Bum-in Charge }: 2 \\
\text { Bum-in Charge } 22\end{array}$ & $\begin{array}{l}10 \\
10\end{array}$ & $\begin{array}{l}\mathrm{C} 20 \\
\mathrm{C} \Omega\end{array}$ & $\begin{array}{l}1.53 \\
1.53\end{array}$ & $\begin{array}{l}0.80 \\
0.80\end{array}$ & $\begin{array}{r}23 \\
1\end{array}$ & - \\
\hline $\begin{array}{l}16 \\
17\end{array}$ & $\begin{array}{l}11 \\
12\end{array}$ & $\begin{array}{l}\text { Bum-in Charge } 3 \\
\text { Bum-in Discharge } 3\end{array}$ & $\begin{array}{l}10 \\
10\end{array}$ & $\begin{array}{l}\mathrm{C} 20 \\
\mathrm{C} \Omega\end{array}$ & $\begin{array}{l}1.53 \\
1.53\end{array}$ & $\begin{array}{l}0.80 \\
0.80\end{array}$ & $\begin{array}{r}23 \\
1\end{array}$ & - \\
\hline $\begin{array}{l}18 \\
19\end{array}$ & $\begin{array}{l}11 \\
12\end{array}$ & $\begin{array}{l}\text { Bum-in Charge } 4 \\
\text { Bum-in Discharge } 4\end{array}$ & $\begin{array}{l}10 \\
10\end{array}$ & $\begin{array}{l}\mathrm{C} 20 \\
\mathrm{C} n\end{array}$ & $\begin{array}{l}1.53 \\
1.53\end{array}$ & $\begin{array}{l}0.80 \\
0.80\end{array}$ & $\begin{array}{r}23 \\
1\end{array}$ & - \\
\hline $\begin{array}{l}22 \\
23\end{array}$ & $\begin{array}{l}11 \\
12\end{array}$ & $\begin{array}{l}\text { Bum-in Charge } 6 \\
\text { Bum-in Dischage } 6\end{array}$ & $\begin{array}{l}10 \\
10\end{array}$ & $\begin{array}{l}\mathrm{C} 20 \\
\mathrm{C} \Omega\end{array}$ & $\begin{array}{l}1.53 \\
1.53\end{array}$ & $\begin{array}{l}0.80 \\
0.80\end{array}$ & $\begin{array}{r}23 \\
1\end{array}$ & - \\
\hline 24 & $\begin{array}{l}11 \\
12\end{array}$ & $\begin{array}{l}\text { Bum-in Charec } 7 \\
\text { Bum-in Discharge } 7\end{array}$ & $\begin{array}{l}10 \\
10\end{array}$ & $\begin{array}{l}\mathrm{C} / 20 \\
\mathrm{C} / 20\end{array}$ & $\begin{array}{l}1.53 \\
1.53\end{array}$ & $\begin{array}{l}0.80 \\
0.80\end{array}$ & $\begin{array}{r}2.1 \\
1\end{array}$ & - \\
\hline 26 & $\begin{array}{l}11 \\
13\end{array}$ & $\begin{array}{l}\text { Bum-in Charge ox } \\
\text { Bum-in Capicily Dixharge } \\
\text { Revivive Draintenipersture Sishiliestion }\end{array}$ & $\begin{array}{l}10 \\
10 \\
20\end{array}$ & $\begin{array}{l}\mathrm{C} / 20 \\
\mathrm{C} / 2 \\
-\end{array}$ & $\begin{array}{l}1.53 \\
1.53 \\
-\end{array}$ & $\begin{array}{l}0 . \times 0 \\
0 . \times n \\
-\end{array}$ & $\begin{array}{r}23 \\
-1 \\
-\end{array}$ & $\bar{z}$ \\
\hline $\begin{array}{l}2 x \\
29\end{array}$ & 5 & $\begin{array}{l}\text { Capucily Charge } \\
\text { Capucily Dicuhage } \\
\text { Resivive Drain }\end{array}$ & $\begin{array}{l}20 \\
20 \\
20\end{array}$ & $\begin{array}{c}C / 10 \\
C / 2 \\
-\end{array}$ & $\begin{array}{c}1.51 \\
1.51 \\
-\end{array}$ & $\begin{array}{c}10 \times 0 \\
0 \times 0 \\
-\end{array}$ & $\begin{array}{l}24 \\
-\end{array}$ & $\overline{3}$ \\
\hline
\end{tabular}


Table 2. Operating Parameters for NWSC Life Test Packs

6AH Pack

12AH Pack

Life cycling regime

Duration (year, real time)

Temperature $\left({ }^{\circ} \mathrm{C}\right)$

Depth-of-discharge (\%)

Orbit

Charge

Discharge

\section{GEO}

1

10

80

25 day Eclipse

$\mathrm{C} / 10$

$\mathrm{C} / 1.5$ (Eclipse)
LEO

1

0

40

$90 \mathrm{~min}$

$\mathrm{C} / 1.25$

$\mathrm{C} / 1.25$ 


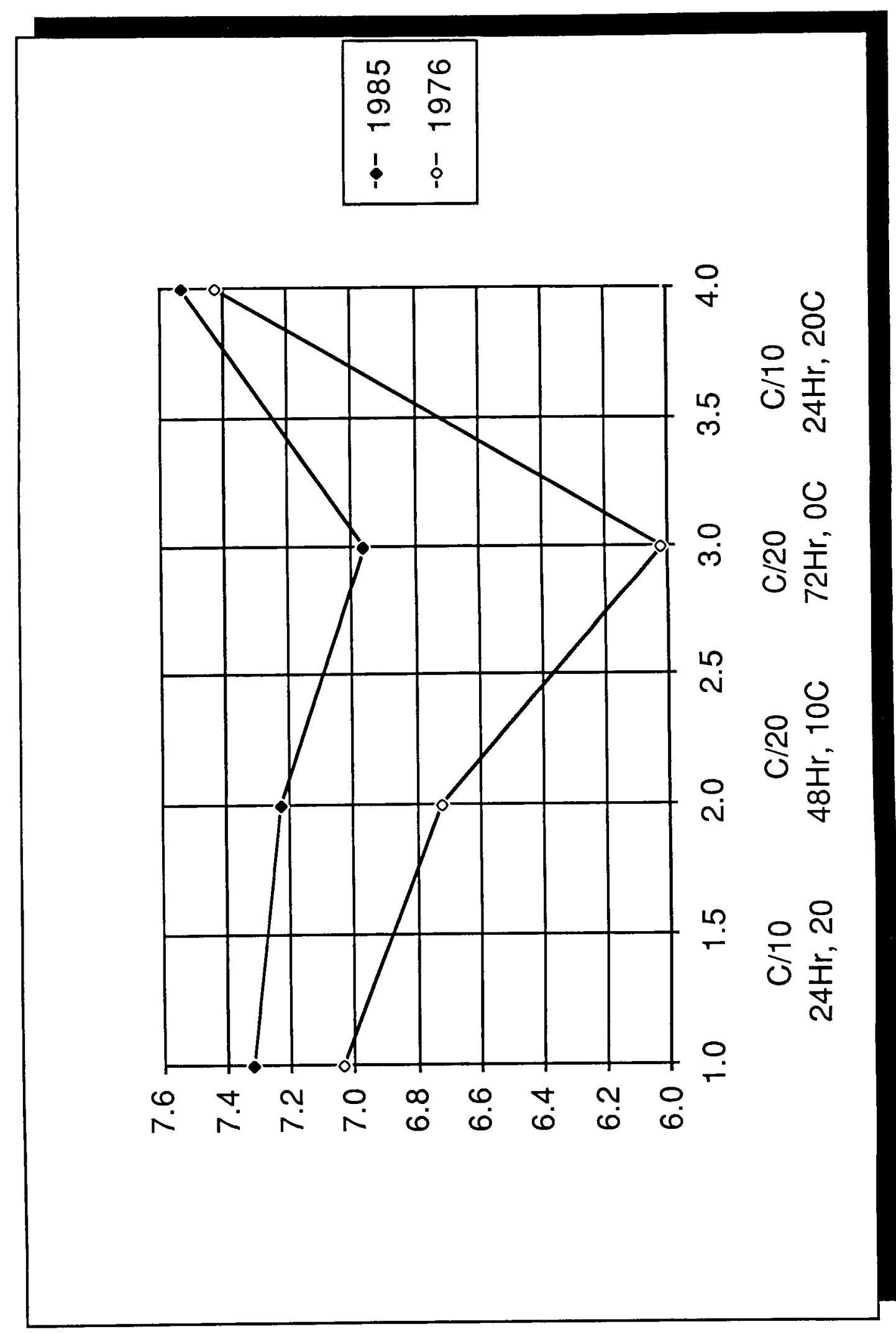




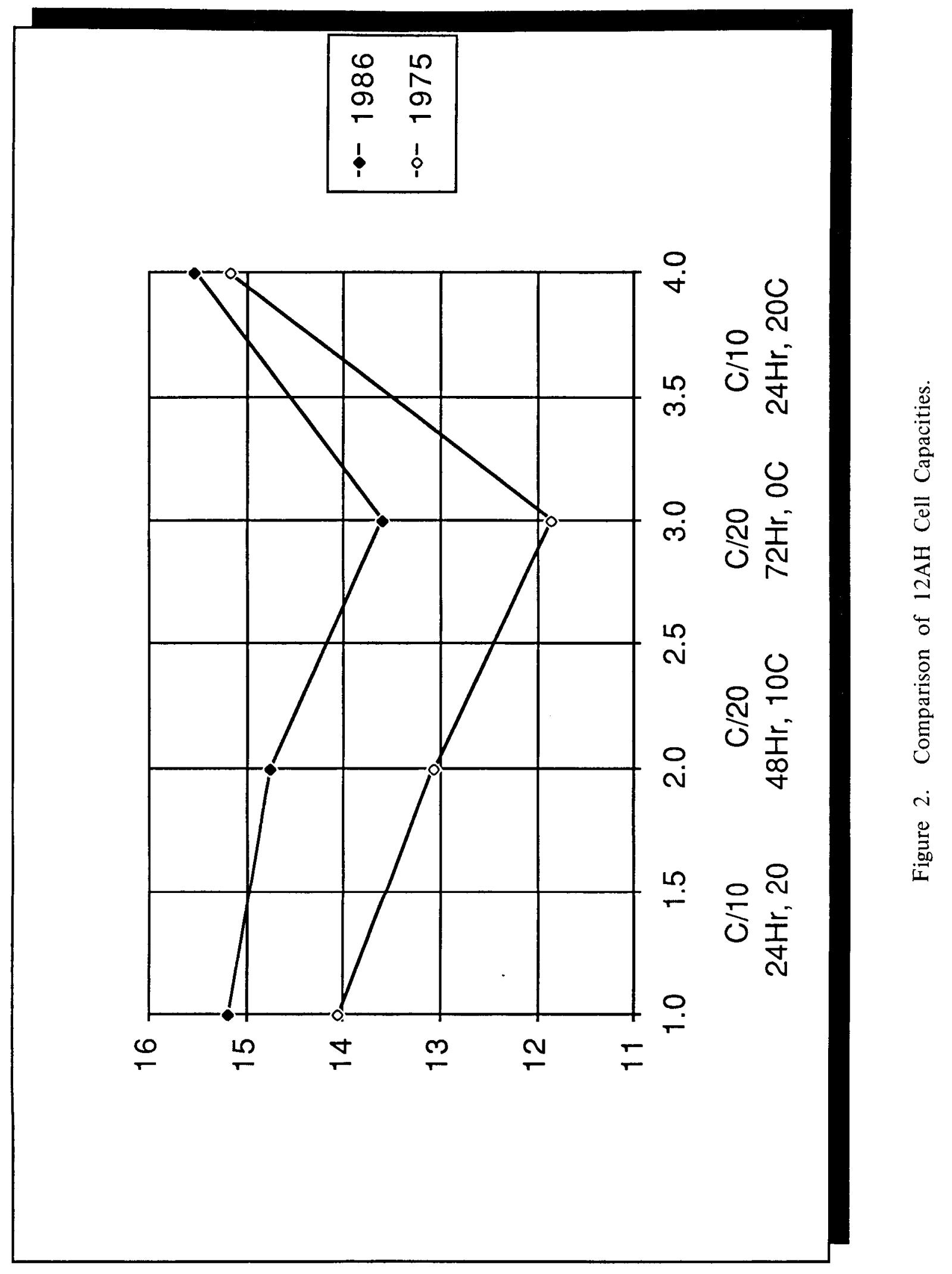




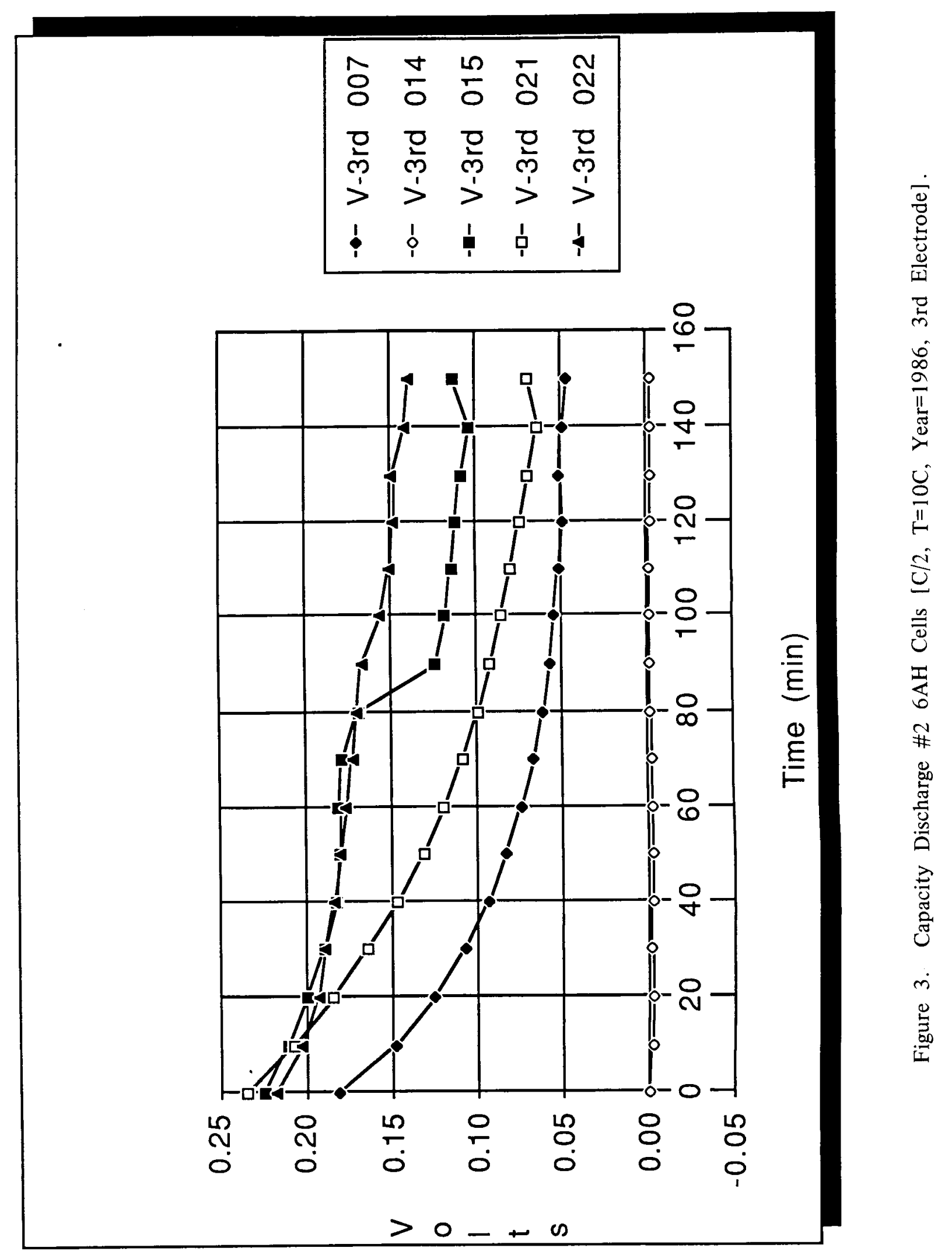




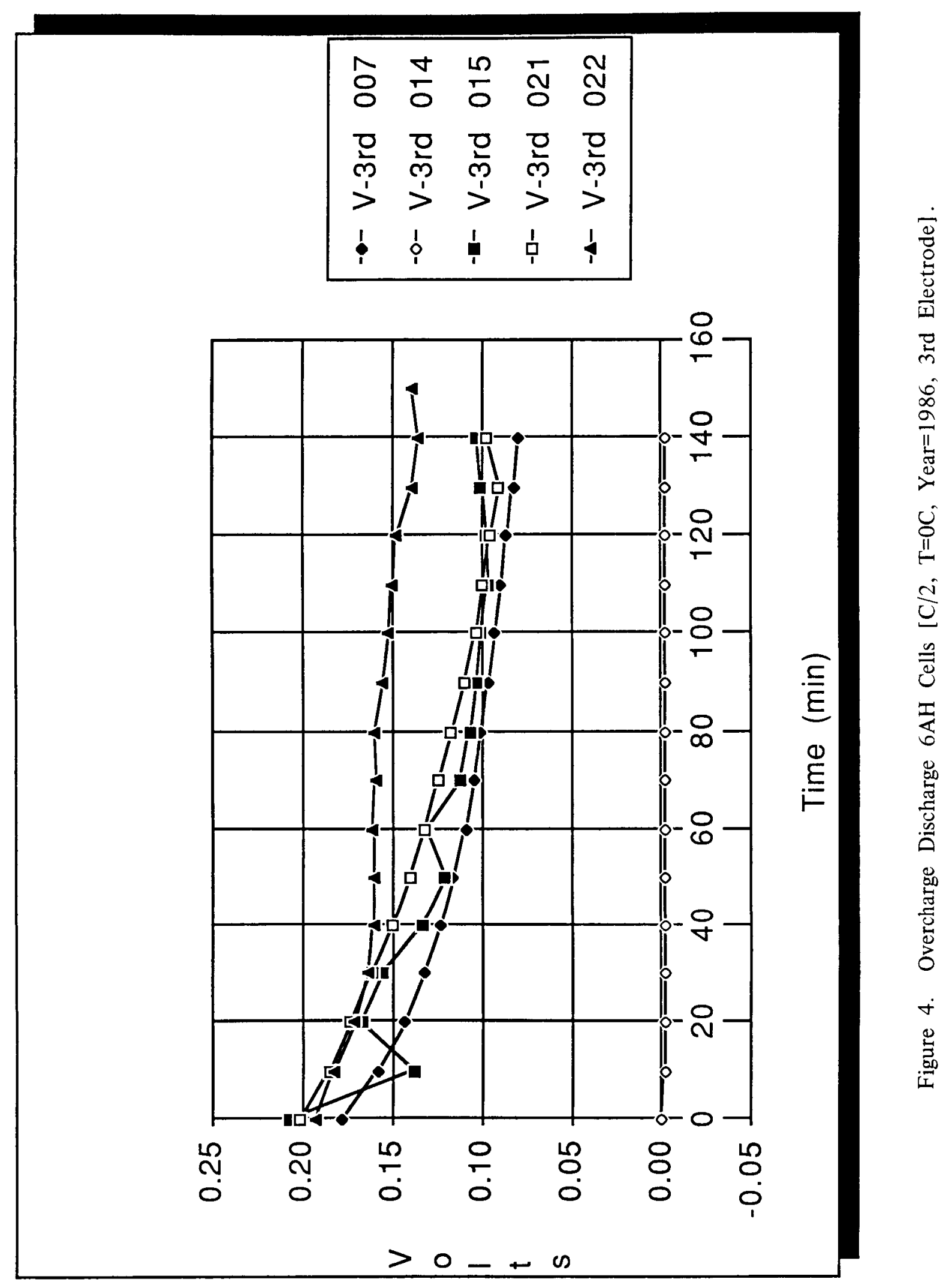




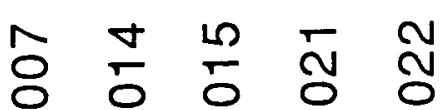

$$
\begin{aligned}
& \begin{array}{lllll}
0 & 0 & 0 & 0 & 0 \\
\frac{0}{2} & \frac{0}{2} & m & m & m \\
\dot{m} & 1 & 1 & 1 & > \\
> & > & > & > & >
\end{array} \\
& \text { ! } 1 \vdots 1
\end{aligned}
$$

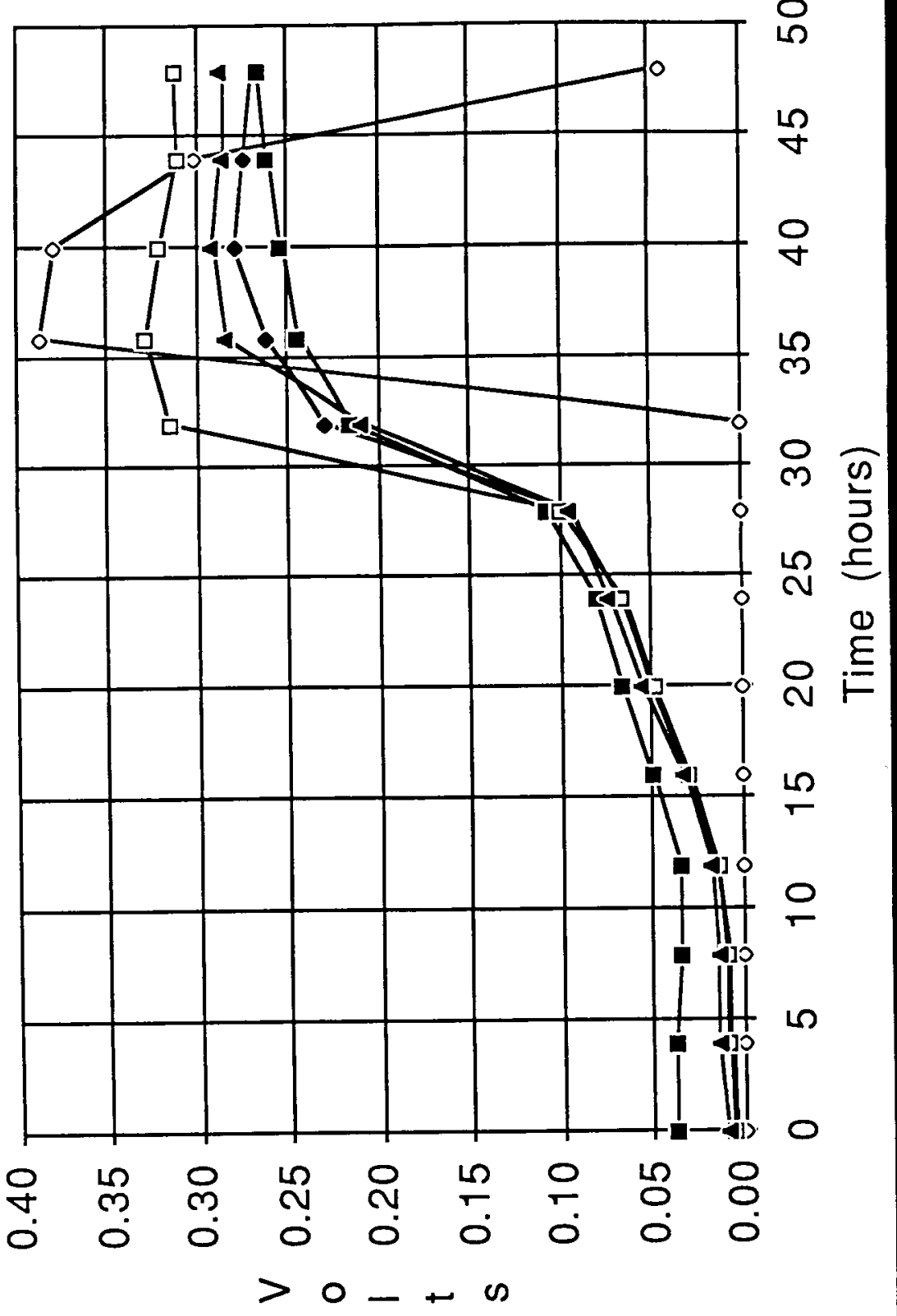




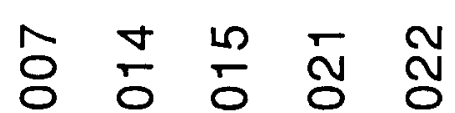

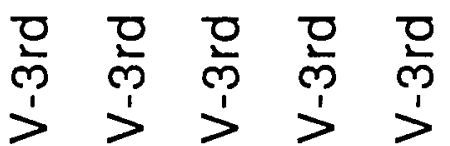

$$
\begin{aligned}
& \text { ! }
\end{aligned}
$$

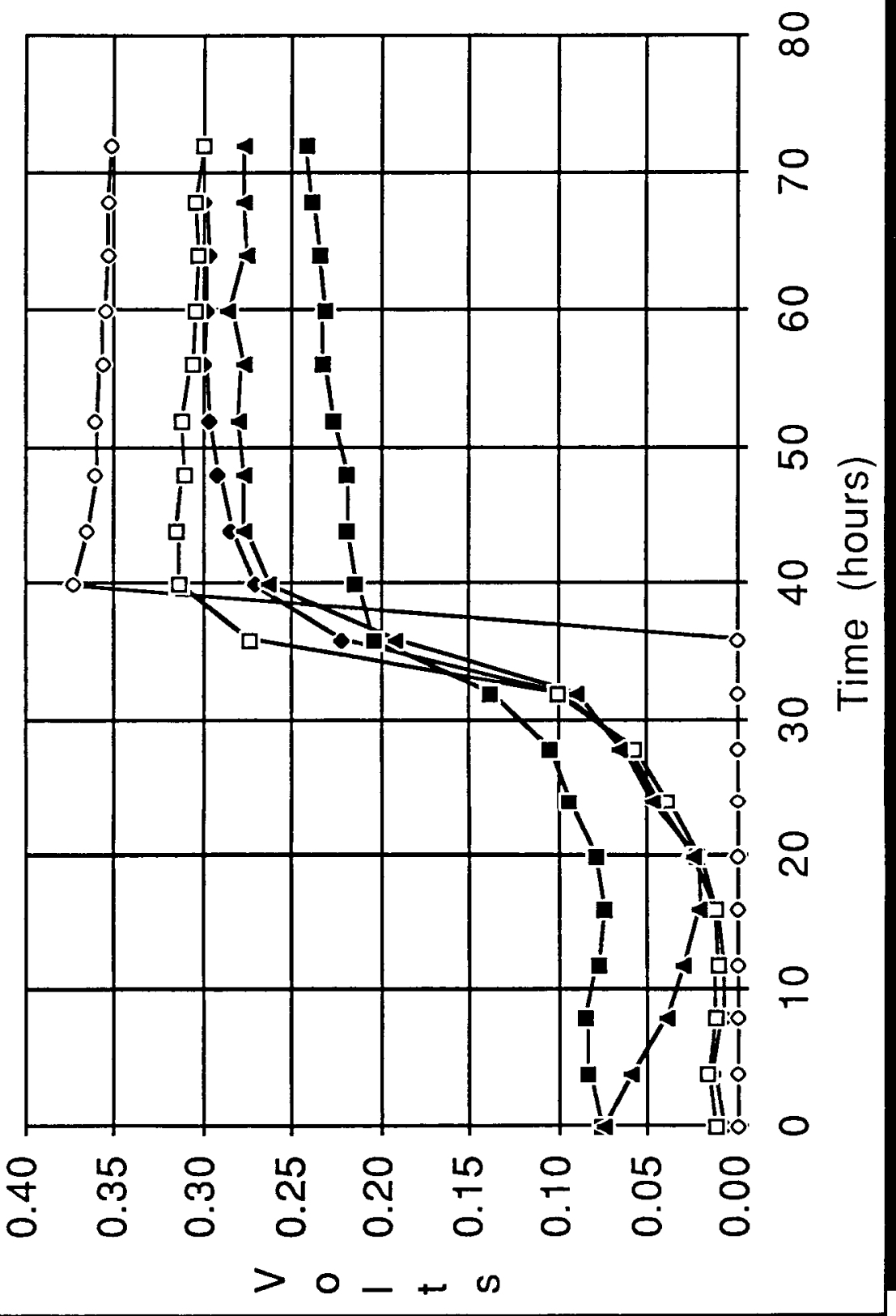

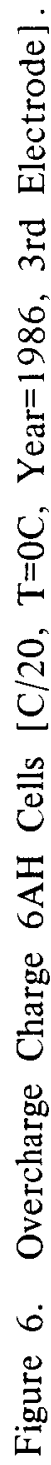




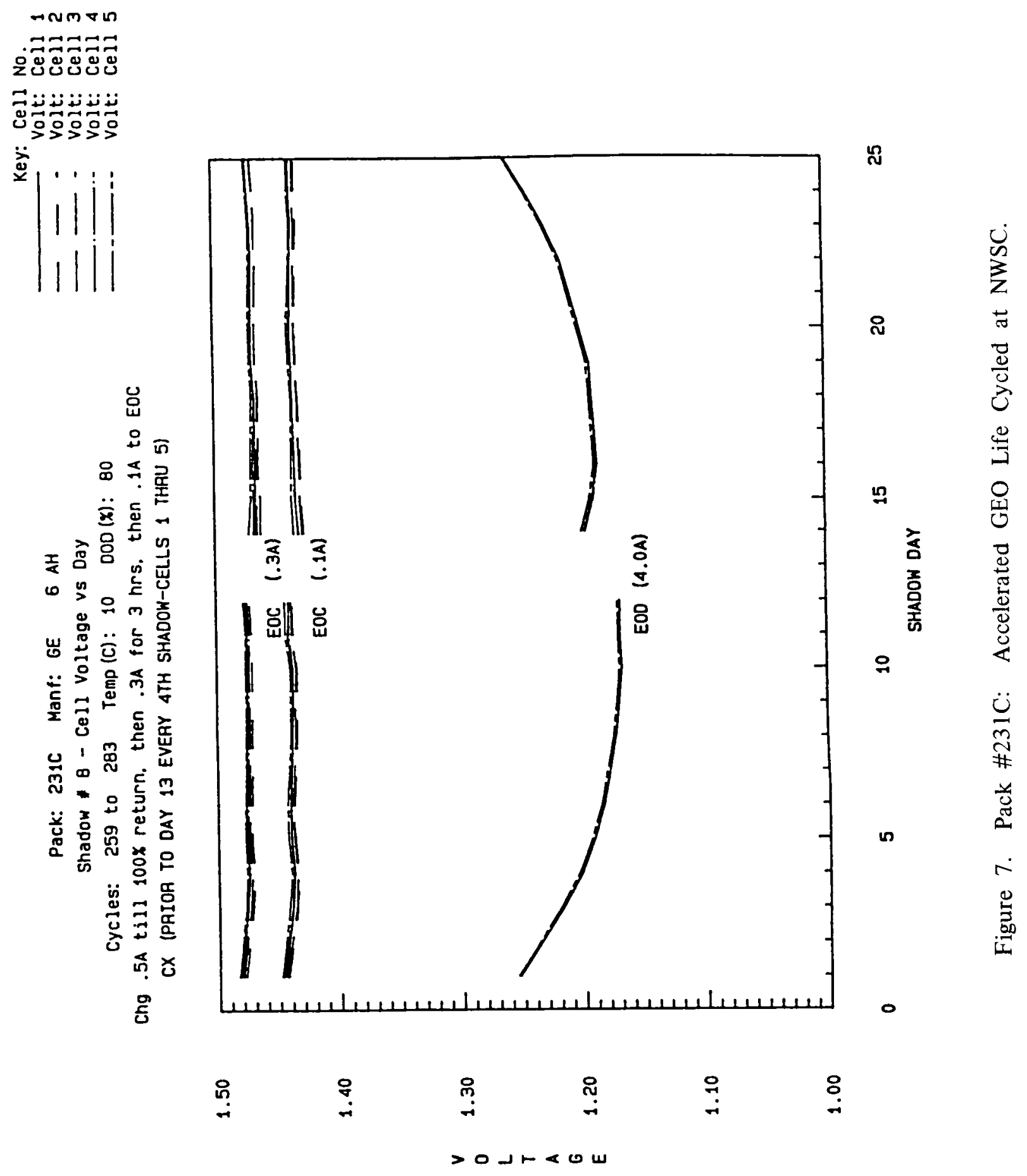




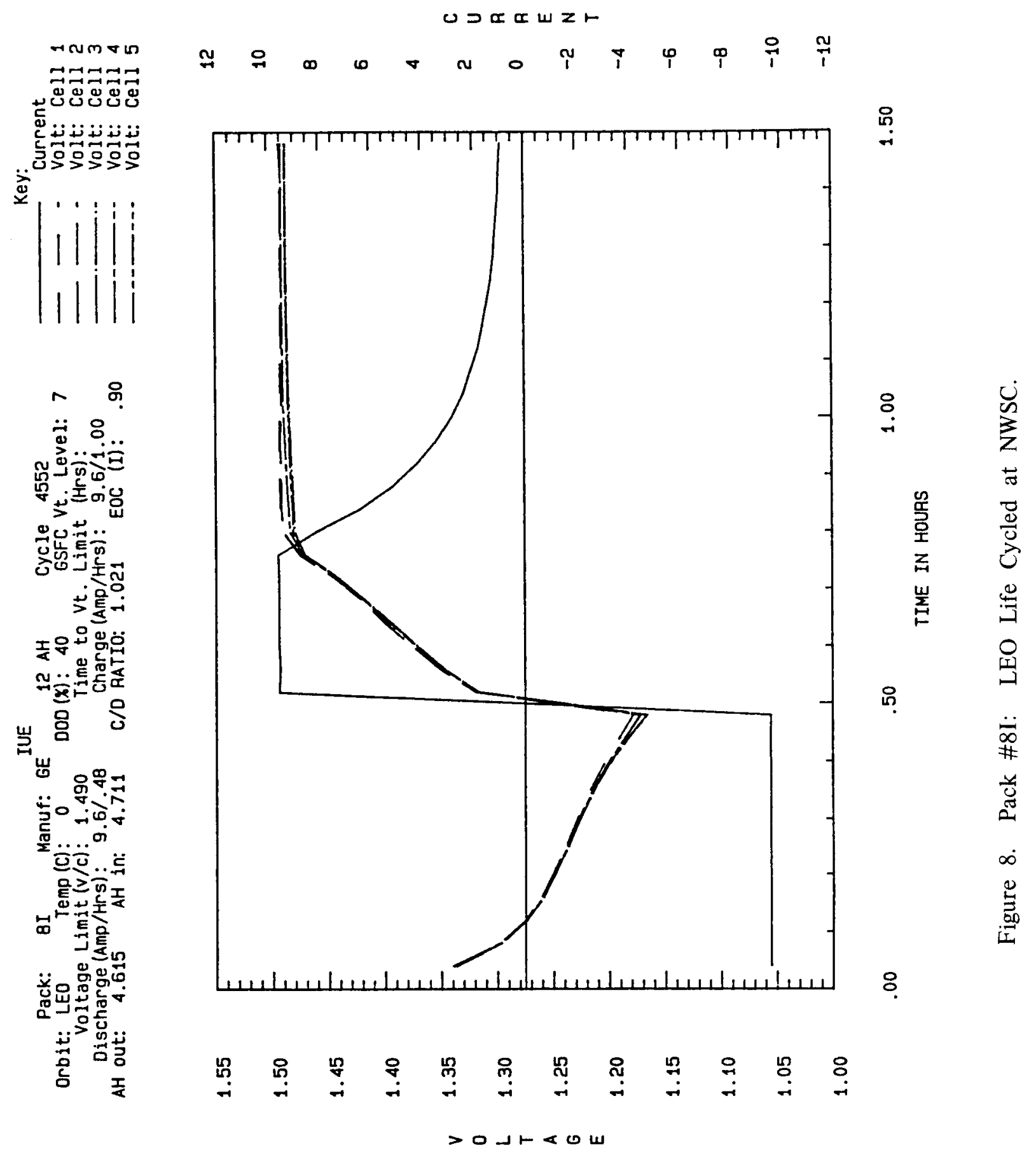




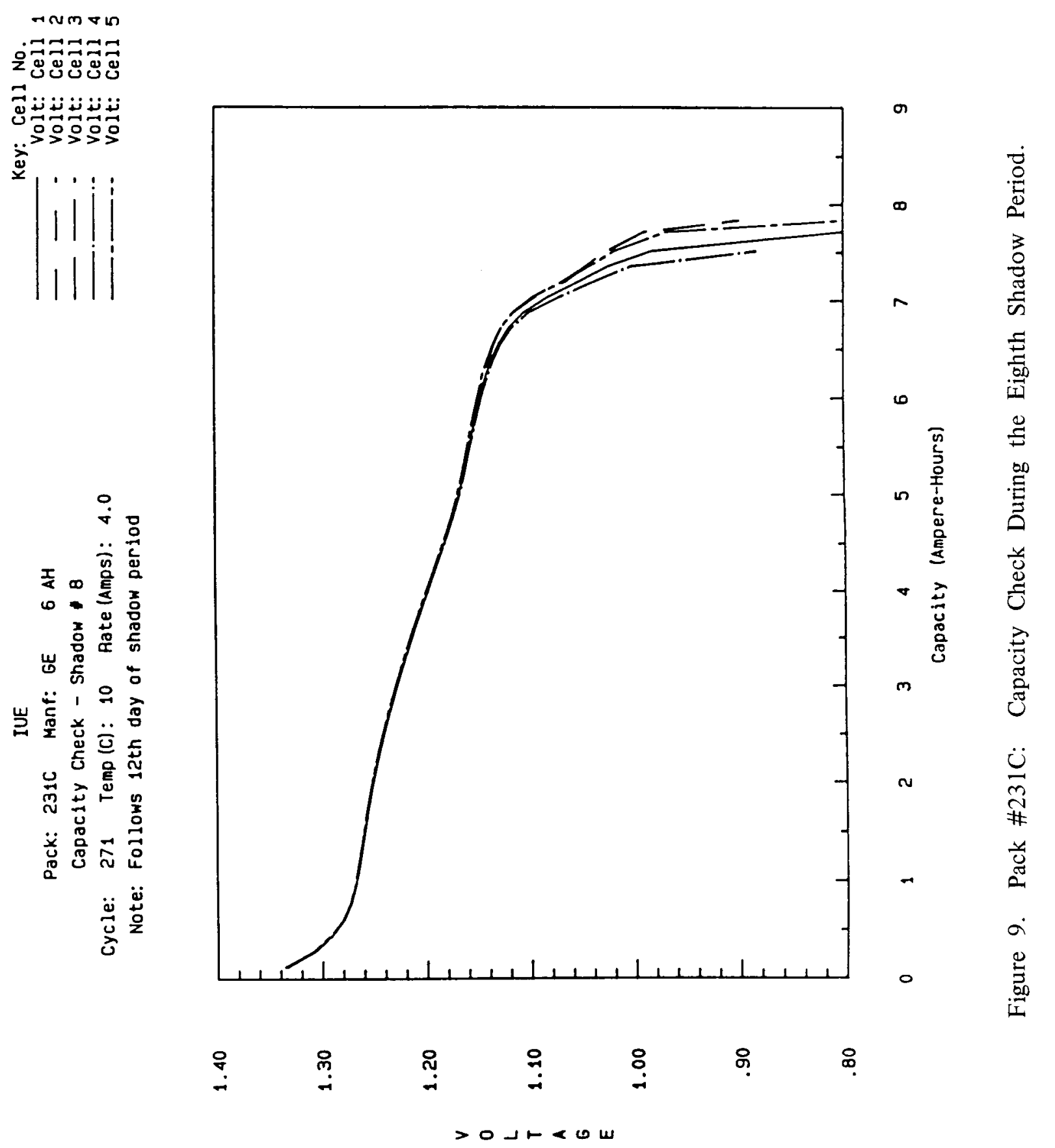

